\title{
Dialogue Translation Shift Analysis in Karyamin's Smile by Ahmad Tohari
}

\author{
Kirana Septiani Wanodya Saputra \\ Universitas Kristen Satya Wacana Salatiga, Indonesia \\ Deta Maria Sri Darta \\ Universitas Kristen Satya Wacana Salatiga, Indonesia \\ Email: deta.darta@uksw.edu
}

\begin{abstract}
A dialogue carries feelings and thoughts of a character in a story. It might also convey emotional expressions. In the translating process, emotional expression, one of many factors which needs to be considered, is regarded as expressive meaning. Thus, in translating dialogues, it is necessary to preserve the emotional expression of the source language. As translation process involves two different languages, there could be changes occurred from ST to TT. Therefore, this study aims to use translation shift to seek the changes in dialogue translation in some short stories in Karyamin's Smile. This research is a qualitative-descriptive analysis as it proposes to identify the types of shift used in dialogue translation and analyze the equivalence to the ST. The dialogues that have been categorized were examined the equivalence using a translation assessment rubric proposed by Khanmohammad and Osanloo (2009). The result shows that each type of shift used more or less affects the equivalence of dialogue translation. The types of shift that are mostly appeared are structure shift and unit shift. Those types produce some patterns. The patterns found in structure shift are passive to active forms, affirmative to interrogative sentence, affirmative to imperative sentence. In unit shift, the patterns found are word to phrase, phrase to sentence, and word to sentence. In sum, structure shift can create more significant changes compared to unit shift as the patterns found mostly result in the changing intention of dialogues.
\end{abstract}

Keywords: dialogue, equivalence, emotional expression, expressive meaning, Translation shift

\section{INTRODUCTION}

To translate words or texts, translators need to use strategies or procedures to help transform the ST to TT equivalently. Translation shift is one of the translation procedures to translate words or texts. Shift according to Hatim and Munday is "the small linguistic changes that occur between ST and TT" (26). In other words, shifts are the changes that happen in translating process. Catford (1965) defines shift as the changes from formal correspondence in the process of going from the SL to the TL. He divides shift into two major types of shift; level shifts and category shifts. Catford also develops category shifts into four types, they are structure-shifts, class-shifts, unit-shifts (rank-changes), intra-system-shifts.

In a story, dialogue is a part which carries feelings and thoughts of the characters. It might also contain the emotional expression of the characters. In translating the dialogue, House (2015) proposes several interacting factors which need to be considered, these are some of them; the structural characteristic, the expressive potential, and the constraints of the two languages involved in translation. She mentions expressive potential which means that translating process in general should not only focus on the structure but the expressive meaning as well. Thus, her theory can be applied in translating dialogues as it concerns about the expressive meaning as well. It is expected that the message and the emotion of the translated dialogue can be as well as if the readers read the original language. Landers states that "translation is rightfully target-oriented" (51).

There were previous studies analyzing shift in translation. For instance, Suhaila (2010) analyzes unit shift in a fiction novel, while Sipayung's research (2018) is translation shift analysis on Billingual History Textbook, and Sunarto (2015) proposes to examine translation shift found in noun phrase in subtitle of a movie written by unofficial subtitle writer. Unit shift is one of the types in category shifts. Thus, the object of Suhaila's only uses one type of the shifts, while Sipayung's uses more types of shift - structure shift, class shift, unit shift, intra system shift in his research. On the other hand, the object of Sunarto's analysis is only the noun phrases found in the subtitle. The difference of this study with those researches is 
that the object which focuses on dialogue translation and this study examines dialogue translation using four types of category shifts.

The necessity of preserving meaning and emotion has been a concern in translating dialogues. Thus, this study will focus on identifying types of translation shifts used in the translated dialogues and how the type of translation shifts used produces equivalent translation. This study attempts to examine the type of shifts used in translating dialogues and analyze the equivalence of shifts used in the TT (English) of Karyamin's Smile (Senyum Karyamin) compared to ST (Indonesian).

This research uses a compilation of short stories by Ahmad Tohari, Senyum Karyamin (Karyamin's Smile). Ahmad Tohari is known as one of the popular Indonesian authors who started his writing career by making short stories. The compilation contains thirteen short stories which were published in many newspapers in the 1970s-1980s era. There will be only several short stories chosen to analyze which contain a lot of conversation due to limited time. The short stories that are used to be examined are Karyamin's Smile, The List of Favours for Sanwirya, and Surabanglus.

Concerning the importance of preserving the message and emotional expression in translating dialogue, this study may be used as a reference in translating dialogues using translation shift and how to preserve the meaning and emotional expressive of the dialogues in ST. Translation major students may use this study as knowledge to help learn about translation. They may also use this analysis as knowledge to get a better understanding of the use of translation shift. This study may not only be used in translation major, students in world literature major can use this research as a reference in understanding literary works.

Newmark defines translation as "rendering the meaning of a text into another language in the way that the author intended the text" (5). Rendering the meaning in the way that the author intended can be interpreted that the focus of translating process should not only be on the structure of language but the messages should be able to be delivered to the target reader (TT). As according to Catford that translation is "the replacement of textual material in one language (SL) by equivalent textual material in another language (TL)" (20). Munday (2008) adds that equivalence has been the prominent issues in translation. The definitions of translation above mostly relate to the description with the issue of equivalence. It strengthens the idea equivalence is one of the concerns in translation.

Shift in Baker (2018) is considered as the changes which occur or may occur in the process of translating. In other words, shift is the changes itself that are produced in the translating process. She also mentions that certain values of expression or content across a semiotic border are part of translation in which shifts are concomitant with this transfer. This is to say that certain values of expression and content are regarded as the essential parts that need to be preserved in order to deliver the messages to the target reader.

The two major types of shift according to Catford (1956) are level shift and category shift. Level shift means that there is a SL term that has different equivalent level in the TL. In other words, there is a different grammatical structure between SL and TL. Category shift is a shift that can occur at all ranks; clause-structure and sentence-structure. The category shift is divided into four types of shift; structure-shifts, class-shifts, unit-shifts (rank-changes), intra-system-shifts. Structure-shift occurs when the structure of language in the TT is different from the ST. This type of shift can be found at other ranks. In grammar, structure-shift can occur at all rank, while classshift happens when the TL has different class from the SL. This is to say that a TL item is possibly a member of a different class from the SL in order to be equivalent. On the other hand, unitshift is defined as the changes of rank in which the translation equivalent of a unit at one rank in the SL is a unit at a different rank in the TL. Meanwhile, intra-system shift, "occurs internally, within a system; that is, for those cases where SL and TL possess systems which approximately correspond formally as to their constitution, but when translation involves selection of a non-corresponding term in the TL system" (80).

Dialogue according to Cambridge Advanced Learner's Dictionary is a conversation written for a book, play or film. A dialogue might not only contain messages. It might carry feelings or the emotional expression of a character. The emotional expression can be referred to expressive meaning, as Baker said, "it relates to the speaker's feelings or attitude rather than to what words and utterances refer to" (13). When translating, Newmark (1988) mentions four levels in general which translators have to bear in mind; SL text level, referential level, cohesive level, level of naturalness. Those four levels are also the important things which can also be considered when translating dialogues. Baker states, "cohesion is the network of surface relations which links 
words and expressions to other words and expression in text" (218). To create dialogue cohesion, there are factors that should be the focus in translating dialogues. Newmark (1988) suggests several considerations when addressing to whom the dialogues are intended to; the kinship and intimacy, class, sex, and age.

\section{METHODOLOGY}

This research is a qualitative-descriptive study as it deals with analyzing the quality of dialogues translation. The source of the data was taken from the text translation of compiled short stories of Karyamin's Smile. The data collected from the chosen short stories which contain a lot of dialogues (Karyamin's Smile, The List of Favours for Sanwirya, and Surabanglus). The number of dialogues in every short story has to be listed before determining which stories to analyze. Only the dialogues which contain translation shifts will be used. The data chosen from the short stories which contain a lot of dialogues in order to get more options to examine since there might be dialogues which do not use translation shifts.

Dialogues in the chosen short stories were sorted regarding the use of translation shift. The dialogues were selected and categorized according to the use of shifts using a comparative table which consists of ST, TT, and type of shift. The analysis used a comparative table to seek the changes from the original language to the target language. The changes include the structure, the meaning, and the emotional expression of the dialogues. Afterward, the comparative table was divided according to the type of shift used (structure shift, class shift, unit shift, intra-system shift) to seek the pattern in each type of shift. Every pattern found in each type of shift were examined to analyze how the shifts used is equivalent to the ST.

\section{RESULTS AND DISCUSSION}

The objective of this research is to identify what types of shift used in translating dialogue and how the type of translation shifts used produces equivalent translation. Thus, this study seeks for the dialogue translation in which translation shift occurred. There are twenty five dialogues found in the ST which contain translation shift from the three short stories chosen. This study divides the discussion into two subs; identifying the type of shift used in the dialogue translation and analyzing the equivalence dialogue translation using a translation quality assessment rubric.

\section{Types of Shift}

There are two major types of shift according to Catford; category and level shift. This study only uses the category shift which consists of four types; structure shift, class shift, unit shift, and intra-system shift. The twenty five dialogues obtained were classified into those four types according to the shift used. The result presents that there are seven dialogues in which structure shift occurred, one dialogue in which class shift happened, fourteen dialogues which are categorized as unit shift, and three dialogues which are identified as intra-system shift.

\section{Structure-shift}

Structure shifts happen when the structure of the sentence from SL to TL changes. There are seven out of twenty five dialogues which contain structure shift from the three short stories chosen. The structure shifts found are done by changing from passive to active form, affirmative to interrogative sentence, interrogative to imperative sentence. Eastwood (1994) in Oxford Guide to English Grammar mentions that there are four types of sentence; statement, question, imperative, and exclamation. Those four types of sentence possess different structure. Therefore, structure shift can happen when there is a transformation from one to another type of sentence.

\section{Structure Shift from Passive to Active Form}

The changing from passive to active form occurs due to the transformation of the sentence from ST to TT. Generally, active form is marked when the subject acts something and the position of the subject is put at the beginning of the sentence whereas the subject in passive form receives the action of the verb and is put at the end of the sentence. The Table 1 presents the result.

The data shows that all the changes from passive to active form occurs from ST to TT. The ST (Indonesian) uses the passive form and the TT (English) uses active form. This pattern might be a sign that it is more natural to use active form in direct conversation since all the dialogues in TT are in active form rather than preserving the passive form in the ST.

\section{Structure Shift from Affirmative to Interrogative Sentence}

Affirmative refers to positive statements, while interrogative relates to questions. The changing from affirmative to interrogative sentence and vice versa is categorized as structure shift as the structure and the purpose of the sentence is different. The order of subject, verb, and 
object is also put differently. The table below is the dialogue translations identified as structure shift done by changing the affirmative to interrogative sentence.

The finding shows that the unit shift that happens from affirmative to interrogative does not occur in the other way. It is rarely found the shift from interrogative to affirmative sentence.

\section{Structure Shift from Interrogative to Imperative sentence}

Interrogative sentence aims to give questions. On the other side, imperative sentence is meant to give order to someone. The contrasting function of those two types of sentence also possesses different structure. Nonetheless, if there is a change from interrogative to imperative sentence, it is regarded as structure shift as they both possess different structure. The example is the interogative sentence in ST "Hayo cepat; mana uang iuranmu?" is translated into "Come on, give me your donation!". The use of punctuation clearly expresses that there is a change of type of sentence from ST to TT.

\section{Class-shift}

When there is a different class of item between ST and TT, it is categorized as class-shift. In other words, when there is a part of speech in the ST that is changed in the TT, it can be classified as class shift.

\section{Class-shift Verb to Noun}

Ideally, a verb in the ST could be translated as a verb in the TT. However, since every language might not have the equal word for another language, it is possible that class shift occurs in the translating process. The example taken from the text shows that a verb is translated into a noun: the sentence in ST "Kami belum pergi dari sini karena kami sudah sepakat akan mengasihani suamimu." Is translated into "We are still here and we've decided to show our sympathy."

The word "mengasihani" (have mercy on someone) in the ST is a verb, while "sympathy" in the TT is a noun. It clearly shows that there is a class-shift happened since a verb in the ST has been changed into a noun

\section{Unit shift}

As explained in the theory that unit shift is the changes of rank in which the translation equivalent of a unit at one rank in the SL is a unit at a different rank in the TL. The data found that the unit shift used in the dialogues happens from word to phrase and vice versa, phrase to sentence, and phrase to word.

\section{Unit shift from Word to Phrase and Vice Versa}

Phrase according to the book Collins Cobuild English Grammar is "a set of words that is smaller than a clause, and that is based around a particular word class". It obviously explains that phrase and word belong to different rank.

Table 1. Structure Shift from Passive to Active Form

\begin{tabular}{lll}
\hline ST & TT & Type of Shift \\
\hline $\begin{array}{l}\text { Sudah, Min. Pulanglah. Kuki- } \\
\text { ra hatimu tertinggal di rumah }\end{array}$ & $\begin{array}{l}\text { That's it, Min. Just go home. I } \\
\text { think you left your heart at home, }\end{array}$ Passive form $\rightarrow$ Active form \\
sehingga kamu loyo terus & that's why you're so lethargic & \\
$\begin{array}{l}\text { Pulanglah. Istrimu kini pasti } \\
\text { sedang digodanya. }\end{array}$ & $\begin{array}{ll}\text { Go home. I bet they are flirting } \\
\text { with your wife right now. }\end{array}$ & $\begin{array}{l}\text { Structure shift } \\
\text { Passive form } \rightarrow \text { Active form } \\
\text { Dia yang kusewa mobilnya }\end{array}$ \\
& I rented the car from him. & Structure shift \\
& & Passive form $\rightarrow$ Active form \\
\hline
\end{tabular}

Table 2. Structure Shift from Affirmative to Interrogative sentence

\begin{tabular}{|c|c|c|}
\hline ST & TT & Type of Shift \\
\hline $\begin{array}{l}\text { Jangan kira mereka hanya } \\
\text { datang setiap hari buat me- } \\
\text { nagih setoran kepada istrimu. }\end{array}$ & $\begin{array}{l}\text { Do you really think they } \\
\text { come every day to ask for } \\
\text { debt payments to your wife? }\end{array}$ & $\begin{array}{l}\text { Structure shift } \\
\text { Affirmative } \rightarrow \text { Interrogative } \\
\text { Sentence }\end{array}$ \\
\hline $\begin{array}{l}\text { Kamu diam saja, apakah } \\
\text { kamu tidak melihat ikan pu- } \\
\text { tih-putih sebesar paha? }\end{array}$ & $\begin{array}{l}\text { Why are you so quiet? Do } \\
\text { not you see those thigh-sized } \\
\text { white fish? }\end{array}$ & $\begin{array}{l}\text { Structure shift } \\
\text { Affirmative } \rightarrow \text { Interrogative } \\
\text { Sentence }\end{array}$ \\
\hline $\begin{array}{l}\text { Aku mau lihat koran kema- } \\
\text { rin, atau hari ini }\end{array}$ & $\begin{array}{l}\text { Can I please see yesterday's } \\
\text { or today's paper? }\end{array}$ & $\begin{array}{l}\text { Structure shift } \\
\text { Affirmative } \rightarrow \text { Interrogative } \\
\text { Sentence }\end{array}$ \\
\hline
\end{tabular}


Nevertheless, when a word in the ST changes into phrase in TT and vice versa means that there is unit shift due to the change of rank.

\section{Unit shift from Phrase to Sentence}

The definition of sentence according to Collins Cobuild English Grammar is "a group of words that express a statement, question, or command". On the contrary, phrases are just a group of words smaller than clauses. A phrase cannot express a statement, question, or command. It means that a sentence provides information more than a phrase. Thus, this change is also regarded as unit shift due to the change of rank level in the TT.

\section{Unit shift from Word to Sentence}

Unit shift is explained as the changes of ranks. It can occur at all ranks. It is possible to happen from a smaller to a bigger rank and vice versa. The example below indicates the use of unit shift as the ST is considered at the word level and it is changed into a sentence. It obviously presents the change of rank from word to sentence.

\section{Intra-system shift}

Intra-system shift found in the dialogue translation mostly deals with the different system of plural and singular in each language. This analysis found how the system of plural and singular between the SL and TL different.

\section{Intra-system Shift from Singular to Plural}

The use singular and plural for noun helps to distinguish the number of nouns. Plural nouns mean that the number of nouns is more than one. Meanwhile singular noun indicates that the number of the noun is only one. When the noun in the ST changes from singu-

Table 3. Unit shift from Word to Phrase and Vice Versa

\begin{tabular}{|c|c|c|}
\hline ST & TT & Type of Shift \\
\hline $\begin{array}{l}\text { Syukur! Marilah. Ada banyak cara } \\
\text { untuk merasa kasihan kepada pen- } \\
\text { deres itu. }\end{array}$ & $\begin{array}{l}\text { Good! Let's discuss it. There are many } \\
\text { ways to express our sympathy to the } \\
\text { tap sapper. }\end{array}$ & $\begin{array}{l}\text { Unit shift } \\
\text { Word } \rightarrow \text { Phrase }\end{array}$ \\
\hline $\begin{array}{l}\text { Nah, begitu! Kita akan menunjuk- } \\
\text { kan diri kita sebagai si putus asa } \\
\text { sesudah bergelandang selama tujuh } \\
\text { tahun. }\end{array}$ & $\begin{array}{l}\text { There! We shall show that we are the } \\
\text { desperate people who have been won- } \\
\text { dering around for seven years. }\end{array}$ & $\begin{array}{l}\text { Unit shift } \\
\text { Phrase } \rightarrow \text { Word }\end{array}$ \\
\hline Menolong? & Help us? & $\begin{array}{l}\text { Unit Shift } \\
\text { Word } \rightarrow \text { Phrase }\end{array}$ \\
\hline Bung mau berbicara soal koperasi! & $\begin{array}{l}\text { So the gentleman here wants to dis- } \\
\text { cuss about the cooperative enterprise! }\end{array}$ & $\begin{array}{l}\text { Unit shift } \\
\text { Word } \rightarrow \text { Phrase }\end{array}$ \\
\hline $\begin{array}{l}\text { Yang pertama-tama harus kita se- } \\
\text { lenggarakan adalah makanan untuk } \\
\text { keluarga Sanwirya. }\end{array}$ & $\begin{array}{l}\text { First, we must think about the food for } \\
\text { Sanwirya's family. }\end{array}$ & $\begin{array}{l}\text { Unit shift } \\
\text { Phrase } \rightarrow \text { Word }\end{array}$ \\
\hline
\end{tabular}

Table 4. Unit shift from Phrase to Sentence

\begin{tabular}{|c|c|c|}
\hline ST & TT & Type of Shift \\
\hline Pekerjaan calo. & He was a ticket scalper & $\begin{array}{l}\text { Unit shift } \\
\text { Phrase } \rightarrow \text { Sentence }\end{array}$ \\
\hline $\begin{array}{l}\text { Apa kataku! Yang seorang ini akan } \\
\text { mulai dengan yang sulit-sulit. }\end{array}$ & $\begin{array}{l}\text { What did I tell you? This one will } \\
\text { start with complicated stuff. }\end{array}$ & $\begin{array}{l}\text { Unit shift } \\
\text { Phrase } \rightarrow \text { Sentence }\end{array}$ \\
\hline $\begin{array}{l}\text { Kau menyuruh kami meminta ubi } \\
\text { kayu? Tak mungkin! }\end{array}$ & $\begin{array}{l}\text { You ask us to beg for cassava? That's } \\
\text { impossible! }\end{array}$ & $\begin{array}{l}\text { Unit shift } \\
\text { Phrase } \rightarrow \text { Sentence }\end{array}$ \\
\hline Ceritanya mengesankan. Gali ya? & $\begin{array}{l}\text { His stories were very impressive. } \\
\text { He's a robber, isn't he? }\end{array}$ & $\begin{array}{l}\text { Unit shift } \\
\text { Phrase } \rightarrow \text { Sentence }\end{array}$ \\
\hline Tak perduli yang mana maksudmu. & I do not care what all of you mean. & $\begin{array}{l}\text { Unit shift } \\
\text { Phrase } \rightarrow \text { Sentence }\end{array}$ \\
\hline Kasihan dia & I really pity him & $\begin{array}{l}\text { Unit Shift } \\
\text { Phrase } \rightarrow \text { Sentence }\end{array}$ \\
\hline
\end{tabular}


Table 5. Unit shift from Word to Sentence

\begin{tabular}{lll}
\hline ST & TT & Type of Shift \\
\hline Setuju? & Do you all agree? & $\begin{array}{l}\text { Unit shift } \\
\text { Word } \rightarrow \text { Sentence }\end{array}$ \\
Kasihan & I pity him & $\begin{array}{l}\text { Unit Shift } \\
\text { Word } \rightarrow \text { Sentence }\end{array}$ \\
Sudah, Min. Pulanglah. & That's it, Min. Just go home. & $\begin{array}{l}\text { Unit shift } \\
\text { Word } \rightarrow \text { Sentence }\end{array}$ \\
& &
\end{tabular}

Table 6. Intra-system shift from Singular to Plural

\begin{tabular}{|c|c|c|}
\hline ST & TT & Type of Shift \\
\hline $\begin{array}{l}\text { Batumu juga belum dibayarnya, } \\
\text { kan? }\end{array}$ & He hasn't paid for your stones, right?? & $\begin{array}{l}\text { Intra-system shift } \\
\text { Singular } \rightarrow \text { Plural }\end{array}$ \\
\hline $\begin{array}{l}\text { Istrimu tidak hanya menarik mata } \\
\text { petugas bank harian. }\end{array}$ & $\begin{array}{l}\text { Your wife is not only attractive for } \\
\text { those daily bank officers. }\end{array}$ & $\begin{array}{l}\text { Intra-system shift } \\
\text { Singular } \rightarrow \text { Plural }\end{array}$ \\
\hline $\begin{array}{l}\text { Musim ini semua orang hanya } \\
\text { menanam ubi estepe sebab celeng } \\
\text { dan monyet tak mau menyukain- } \\
\text { ya. }\end{array}$ & $\begin{array}{l}\text { This season everybody only planted } \\
\text { the STP cassava because the boars and } \\
\text { the monkeys do not like those types. }\end{array}$ & $\begin{array}{l}\text { Intra-system shift } \\
\text { Singular } \rightarrow \text { Plural }\end{array}$ \\
\hline
\end{tabular}

lar to plural and vice versa, it means that the ST has experienced the use of intra-system shift.

The finding shows that the singular nouns in the ST have been changed into plural in the TT. This changing is regarded as intrasystem shift due to the number of nouns that has been changed in the TT.

\section{Dialogue Translation Analysis}

This part seeks how the type of shift used creates equivalent dialogue translation and assess them using an adapted rubric. The dialogues which have been categorized based on the types of shift used are analyzed according to the rubric. The rubric for translation quality assessment adapted from Hajar Khanmohammad and Maryam Osanloo (2009), in their journal entitled Moving toward Objective Scoring: A Rubric for Translation Assessment. They proposed a new translation quality assessment rubric by collecting several translation quality assessment rubrics and then recreated them into a new formula. Below is the new rubric proposed.

Table 7. Rubric

\begin{tabular}{ll}
\hline Items & Score \\
\hline Accuracy & $30 \%$ \\
Finding equivalent words & $25 \%$ \\
Register & $20 \%$ \\
Grammar and Preservation of Style & $15 \%$ \\
Shifts, Addition, Omission & $10 \%$ \\
\hline
\end{tabular}

There are some items in the rubric which the total of the whole assessment must be $100 \%$. Accuracy achieves the highest point when the translation could convey the original message completely to the target readers without omission or addition. The lexical choices used in the translation is assessed as the ability to find equivalent word. It refers to the vocabularies used to make the translation equivalent to the ST. In the rubric, register relates to the cultural context. On the other hand, grammar and preservation of style concern about grammatical issues of the TT and the native-like fluency in grammar. Lastly, shift, addition, and omission focus on the use of shift, addition, and omission in the TT.

\section{Structure Shift}

There are three patterns found in the structure shift; passive to active form, affirmative to interrogative, and interrogative to imperative, and. Among those three patterns, the changing from passive to active form and affirmative to interrogative sentence are the most frequent patterns appear. There are three dialogues found in each pattern

In terms of accuracy, the three patterns found in the structure shift generally produces equivalent meaning in the TT. Accurate translation is achieved when the meaning or message in the ST could be conveyed completely to the target readers. Among the three patterns, the changing form from passive to active creates better transla- 
tion compared to other patterns. It only changes the structure or the order of the words, but does not change a lot of meaning, intention, and emotional expression of the original dialogues. This pattern could be regarded as a good way to bring out the emotional expression of the dialogues and make it sounds interactive as the dialogues in the stories are direct communication.

From the three patterns, the data found that the dialogue translations have no issues about finding the equivalent words. The vocabularies used are still coherent with the ST. In terms of register, the ST has been translated well as it does not transfer any mistranslation in cultural context.

The use of structure shift in the dialogue translation basically does not create grammatical issues. The dialogue is mostly translated well. Even though the structure shifts occurred do not produce grammatical errors, it is found that the changing grammatical structure can result in different intention of the original dialogues in two of three patterns. It happens in the changing from affirmative to interrogative sentence and interrogative to imperative sentence. These patterns show that the different type of sentence between ST and TT creates different intention in the dialogue. For instance, "Kami belum pergi dari sini karena kami sudah sepakat akan mengasihani suamimu" is translated into "We are still here and we've decided to show our sympathy". The ST is meant to ask someone, while the TT tends to give order to someone. In this case, the different type of sentence creates different intention and context which can be interpreted differently by the readers because of the different function between those two types of sentence.

The data present that structure shifts found in the dialogue translation can result in different intention in the TT. Nonetheless, there are two dialogues found in the changing from affirmative to interrogative and interrogative to imperative sentences that still produce equivalent translation even though the structure of the original dialogues has changed. It is due to the connotation meaning that lies in the original dialogues which makes the translated dialogues considered equivalent to the ST. For instance, "Hayo cepat; mana uang iuranmu?" which connotatively intends to order someone to give money. The translation becomes, "Come on, give me your donation!" which obviously aims to give order. It shows that the changing structure occurred for the sake of preserving meaning of the original dialogues. In translating process, it is also possible that the changing of structure due to the shifts occurred produces omission and addition in the TT. Nevertheless, the omission and addition added do not change the message of the original dialogues.

\section{Class Shift}

The changing class from noun to adjective in table 2.1.1 basically still delivers the message well. The translation could convey the intention of the dialogue to TT clearly even though there is a class shift. The vocabularies mostly used in the TT are suitable to the ST which could help the readers to get the meaning. The register in the TT is also fine as it does not contain any mistranslation of cultural contexts. Therefore, the score for accuracy, finding equivalent words, and register get the full point.

In terms of grammar, there is no error found in the TT. Both ST and TT are also in a form of affirmative sentence which aims to state something. The use of shift could help the target readers get the meaning of the dialogue even though there is a change from verb to noun. The word "mengasihani" refers to an act of sympathizing which is a verb and translated into a noun, "sympathy", that is a feeling of caring. There is no omission in the dialogue translation in which class shift occurred, but some additions. However, the use of class shift does not create a huge gap in term of meaning and emotional expression between ST and TT.

\section{Unit Shift}

The limited vocabularies and different registers in the TT result in the use of unit shift occurred in the translation. There are some words that cannot be translated into words and turn to be phrases or sentences. The changing is considered as unit shift. It occurs at all rank. From the three patterns found in the use of unit shift, the shift from phrase to sentence is mostly appeared.

The accuracy of the dialogue translation which uses unit shift is basically close to the ST. The translation still reflects the original meaning of the dialogues. The word choice in the three patterns is also considered appropriate as it preserves the context of the dialogues. In terms of register, the dialogue translation generally does not contain any mistranslation which leads to the gap meaning.

The correct grammar helps target readers to understand the message of the ST. Grammatically, the dialogue translation presented in table 3.1.1, 3.2.1, 3.3.1 which use unit shift does not contain any errors. However, there are omissions and addition in the TT which assist target readers to get the message of the original text better. For 
instance, the subject added in "He was a ticket scalper" is originally a phrase which is without subject. Nevertheless, it could help the target readers to link the dialogue with the whole story. The changes from the small rank to bigger rank result in addition, while in the other way result to omission.

\section{Intra-system shift}

The intra-system shift happened in the dialogue translation generally does not change the entire meaning of dialogues in the ST. Table 4.1.1 shows that the changes deal with the different system of numbering. This is to say that the shift used only changes the quantity of the nouns. The lexical choice used in the translation are regarded suitable that reflects the source language. There is also no misinterpretation in the register from ST to TT.

The dialogue translations in which intrasystem shift occurred do not have grammatical issues which impact to the whole meaning and context. The use of grammar could represent the source language well. The data found some additions in the TT, but it doesn't create different context from the original dialogues. Nonetheless, the dialogue translation in which intra-system shift occurred is basically considered fine as it could still produce equivalent dialogues.

\section{CONCLUSION}

From the three short stories chosen, there are twenty five dialogues in which translation shift occured. The shifts found in the dialogue translation are structure shift, class shift, unit shift, and intra-system shift. The data indicate that the dialogue translation which involves different languages generally results in the changing of structure in the TT. It can be seen in the structure shift and unit shift that occurred in the dialogue translation. There are three patterns found in unit shift; word to phrase, phrase to sentence, and word to sentence. The pattern that mostly appears is phrase to sentence. Every shift more or less creates different sense of meaning in the target language. The different sense of meaning can be caused by the changing intention, limited equivalent words, omission and addition, and also the different system of numbering. Among those factors, the changing intention mostly reveals more significant changes as can be seen in the changing form of sentence from affirmative to interrogative and interrogative to imperative. It may also produce different emotional expression in the dialogue translation which could affect the way the readers perceive the dialogues. However, even though most of dialogue translations in which structure shift occurred result in the changing intention, there are two dialogue translations found that still create equivalent meaning as the message of the original dialogue can be preserved well. While the changes from phrase to sentence which mostly occur in the unit shift basically do not change the meaning of the dialogues, it either reduces or adds the dialogues due to the different rank. To sum up, compared to unit shift, the dialogue translations in which structure shift occurred can result in significant changes of meaning due to the changing intention that mostly appears

\section{REFERENCES}

Bassnett, Susan. (2002). Translation Studies. New York: Routledge.

Baker, M. (2018). In Other Words: A Coursebook on Translation. London \& New York: Routledge.

Catford, J.C. (1956). A Linguistic Theory of Translation. London: Oxford University Press.

Collins Cobuild. (2011). English Grammar. HarperCollins Publishers.

E, Sunarto. (2015). A Translation Shift Analysis Of Noun Phrase In Subtitling Of Ice Age 4 Movie. Thesis. Surakarta: Universitas Muhammadiyah Surakarta. (http://eprints.ums.ac.id/33222/)

Hatim, B. \& J. Munday. (2004). Translation: An advance resource book. USA\&Canada: Routledge.

House, Juliane. (2015). Translation Quality Assessment: Past and present. Londres: Routledge.

Khanmohammad, H.\& M. Osanloo. (2009). Moving toward Objective Scoring: A

Rubric for Translation Assessment. ResearchGate, vol.1.

Landers, E. Clifford. (2001). Literary Translation: A Practical Guide. Great Britain: Cromwell Press Ltd.

Munday, J. (2008). Introducing Translation Studies: Theories and Applications. London\&New York: Routledge.

Newmark, Peter.(1988). A Textbook of Translation. New York: Prentice Hall.

Sipayung, K. Tuahman. (2018). The Impact of Translation Shift and Method on Translation Accuracy Found at Bilingual History Textbook. Humaniora, vol.30.

Suhaila, Suhaila. (2010). Unit-Shift Analysis of English Indonesian Translation of 'The Tale of the. Three Brothers' By J. K. Rowling. Thesis. Jakarta: English Letters Department UIN. (www.repository. uinjkt.ac.id)

Tohari, A. (2015). Senyum Karyamin. Jakarta: PT Gramedia Pustaka Utama.

Tohari, A. (2015) Karyamin's Smile. Transl. Rosemary Kesauly. Jakarta: PT Gramedia Pustaka Utama. 